\title{
Income Security and the Perception of Disability Risk
}

\author{
Marcin Kawiński ${ }^{1}$ and Tadeusz Szumlicz ${ }^{2}$
}

ABSTRACT The concept of income security is almost 80 years old but its implementation, nevertheless, poses a serious social security problem. How is this problem seen today by those most concerned, family households? What is the perception of contingencies listed in the International Labour Organization's (ILO) recommendation? Human responses to risk (behaviour under risk) depend primarily on a perception of risk and disability risk is not different in this respect. It is a major social risk, a part of the list of social risks, and tends to be critical due to financialization and liabilities. This paper aims to find determinants for differences in the perception of disability risk in Poland. The research covers particular determinants and employs qualitative and quantitative methods to analyse such determinants. The qualitative study suggests that the risk of disability is not a primary consideration. The perception of that risk seems to be diverse. Pending liabilities are perceived as arising primarily due to unemployment rather than the lack of fitness for work. An analysis of quantitative data shows statistical importance of chosen determinants (gender, experience regarding disability within family, age, the level of education, and self-estimation of financial situation). However, their significance is limited. Age and education level seem to be most prospective. Young and highly educated people tend to perceive disability risk as relatively low. These are also the people who face the most significant financial consequences of disability.

KEY WORDS: $\quad$ Income, security, disability, risk perception.

JEL Classification: KS1.

SGH Warsaw School of Economics'

University of Economics and Human Sciences in Warsaw, Poland ${ }^{2}$

\section{Introduction}

Human responses to risk (behaviour under risk) depend mainly on one's perception of risk. That is why risk perception is an essential subject of various studies, not only in psychology (Slovic, 2010). Knowledge about differences in risk perception or ways of influencing risk perception becomes crucial for many public and private projects (Bray et al., 2019). Perception of risk is an exciting subject of scientific research that brings valuable input into the theory of behavioural economy (finance) and hints into practical mechanisms within public and private programmes (Paek \& Hove, 2021).

Patterns of risk perception largely depend on the

Correspondence concerning this article should be addressed to:

Tadeusz Szumlicz, University of Economics and Human Sciences in Warsaw, Okopowa 59, Warszawa 01-043 Poland.

E-mail:a. t.szumlicz@vizja.pl type of risk. Hence, the scientific literature describes many studies on different kinds of risks. Studies of many different types reveal that risk perception is often biased. One possible bias is called the white male effect. The white male effect is a phenomenon of lower risk perception among white males. According to a US study, the white male effect has been recognised as applicable to the perception of disability/accidents (Nuru-Jeter et al., 2011; KelleyMoore \& Ferraro, 2004; Manton \& Stallard, 1997).

Each household faces disability risk, mostly covered with social security scheme. The best approach to defining the scope of the social security system is to refer to the classic catalogue of contingencies from the ILO recommendation "income security" (ILO, 1944a) and "medical care" (ILO, 1944b), and convention on "minimum standards of social security" (ILO, 1952). Based on that, there are 
nine contingencies: sickness, maternity, illness, invalidity, death of breadwinner, employment injury, unemployment, old age, emergency expenses; or nine branches (parts) of social security: sickness benefit, maternity benefit, medical care, invalidity benefit, survivors' benefit, employment injury benefit, unemployment benefit, old-age benefit, and family benefit.

Disability risk is a vital social risk, a part of the list of social risks introduced by the ILO in 1944 in the Income Security Recommendation (R067, No. 67). With the increasing importance of hired labour that has turned out to be the only (or the most significant) item of households' income, disability became a primary household risk, included in the ILO Social Security (Minimum Standards) Convention, 1952 (No. 102). However, at that time disability was mostly recognised as a physical impairment. In December 2006, the United Nations (UN) Convention on the Rights of People with Disabilities (UNCRPD) was adopted. This Convention represents an evident shift from the purely medical dimension to a mixed, medical, and social (development) dimension, the latter intended as part-human rights. The Convention defines disabilities in its Article 1, as "long-term physical, mental, intellectual or sensory impairments." Disabilities, in interaction with various barriers, may hinder the full and effective participation of disabled people in society on an equal basis with others.

A wider dimension of disability has been observed based on real-life data. The risk of physical disability has been decreasing over the last decades, primarily due to safer working environments but also thanks to more effective rehabilitation (World Health Organization 2017). At the same time, there is an increasing trend for the diagnosis of mental disorders (OECD/European Union 2020). Although awareness of mental disorders is improving, they have not always been associated with disability as such.

In developed countries, protection against social risks has reached a level significantly exceeding the Social Security Minimum Standards introduced by ILO Convention no. 152. However, the coverage provided by social security schemes cannot keep up with the steadily growing costs of living. Consequently, households affected by disability report difficulties in making ends meet (Figure 1). There are several reasons for the relative decrease in disability benefits, and the most important seem to be budgetary constraints and a lower contribution base due to demographic changes and evolving labour conditions. Even in the case of insurancebased social security schemes (social insurance), the increasing standards of living widen the gap between the actual level of benefits and expectations, lower compensation, and the actual income.

In recent years, a higher standard of living is often financed with money obtained from financial products such as loans, overdraft limits and credit. They are paid off with future income, most frequently from hired labour. It is just one of the signs of the financialization process (Sawyer 2014). "Financialization means the increasing role of financial motives, financial markets, financial actors and financial institutions in the operation of the domestic and international economies." (Epstein, 2005, p.3)

In any case, finalisation is fed by standardisation, and, since households with disabilities are on the margin of the mainstream, they have no or limited access to cheaper products. Furthermore, the process of financialization itself creates the need for additional coverage (from the perspective of disability risk management) due to increasing liabilities under banking products and provides this coverage through insurance products (insurance against the death of a breadwinner or disability). The higher the liabilities are, the more extensive disability coverage is required. The lack of such collateral has potentially severe consequences that could be even greater in the case of the death of a breadwinner. Social security schemes address, in both cases, the risk of disability and that of the death of a breadwinner. Benefits and income decreases while a disabled person requires quite often intensive rehabilitation, usually not fully covered with commercial life insurance.

The importance of additional coverage is growing as public systems cannot ensure a higher standard of disability benefits due to the changes mentioned above. Consequently, the use of commercial 


\section{Figure 1}

Population Living in Households that Reported having Difficulties in Making Ends Meet, 2019.

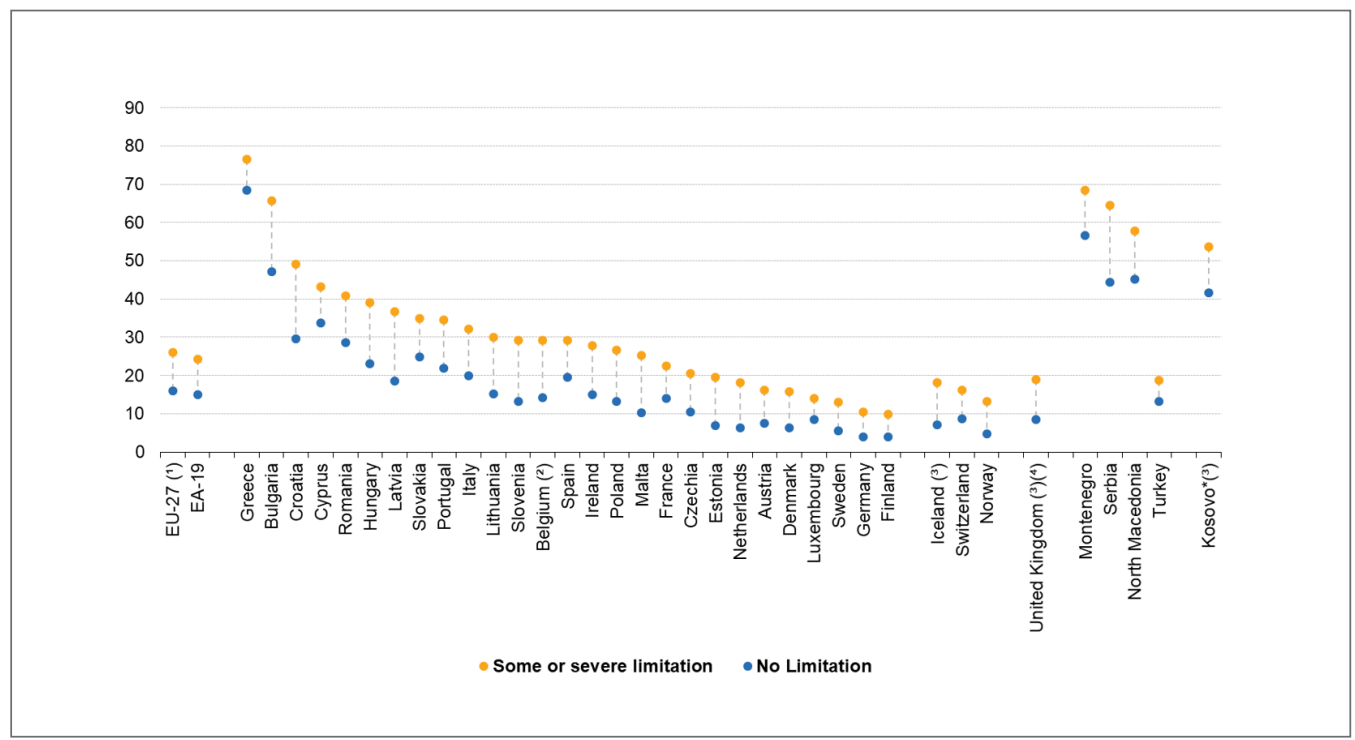

Source: Eurostat

mechanisms is required (Szumlicz, 2015). In this regard, private disability insurance can be an exciting option. Technically, it can be offered by life and nonlife insurance companies. Public-private partnership in social risk management has been continually developing as a very convenient arrangement for both the state and financial markets. Such a partnership features both aspects of a public-private partnership, the privatisation and marketisation of social policies (Hyde \& Dixon, 2001).

By privatisation of a social policy, the state avoids financial risks - private disability insurance products are, after all, voluntary. Nevertheless, the state sets up a regulatory framework for the development of adequate supplementary products. The framework focuses on product design but also could establish certain limitations for providers of disability insurance products. These limitations may positively affect the financial market by generating massive demand for standardised products.

Since private disability insurance products are voluntary and adequate coverage of particular social risks is critical for households' financial security, citizens are offered many different incentives to purchase such products. The most popular ones are tax advantages, behavioural mechanisms, a fixed (safe) construction of products, regulated terms of conditions, a cap on costs and enhanced consumer protection. However, regulators employ such mechanisms mostly in products providing the coverage of health and old-age risks, which are considered extremely important. Disability is given a much lower priority and rarely receives the same attention.

As disability risk falls outside the ambit of the described schemes, the financial market and consumers may freely choose how to approach the matter. There is no rigid framework for product structure and distribution. In the last years, regulations imposed on financial market producers and distributors emphasise the adequacy of coverage and distribution channels, which are to meet the requirements of 'best execution' for policy-holders and insureds.

This paper aims to find potential determinants for differences in the perception of disability risk 
in Poland. Potential socio-economic determinants have been unveiled in studies on the white male effect (Finucane et al., 2000; Kahan et al., 2007). However, due to the demographic structure of Polish society, these determinants must be transformed and adjusted. That is why this research covers the following potential determinants: gender, the experience of disability within the family, age, the level of education and self-assessment of financial situation.

Although there are many studies on risk perception, disability risk has been given little attention by academics. To an extent, this may be the outcome of social protection schemes existing in developed countries that secure basic needs. That is why most of the theoretical framework referred to in this paper comes from general studies on risk perception. These studies mostly cover pure risk (Slovic, 2010), with no potential gains, which is different from speculative risk as defined by the perspective theory (Kahneman \& Tversky, 1979),

Since no studies on the perception of disability risk have been conducted so far, the studies on the 'white male effect' (Finucane et al., 2000; Kahan et al., 2007) offer some preliminary insights as to determinants. Potential determinants include gender, the level of education and self-assessment of financial situation.

\section{Description of Data and Research Method}

The purpose of this study is to identify determinants of the perception of disability risk among households in Poland. Various methods were employed to obtain data for the study purposes: literature review, focus group interviews, a questionnaire survey and the analysis of data of the Polish Social Insurance Institution.

The first step was to identify possible determinants. The performed review of literature, limited due to a small number of studies and a shortage of papers on disability risk, allows identifying gender (white male effect) and age (attitude to different aspects of life). An extended review and previous studies point to the importance of classic demographic determinants, like the level of education and income. A series of qualitative and quantitative studies provided the opportunity of verifying the relevance of the identified determinants.
Qualitative research data was gathered from individual in-depth interviews and focus group interviews conducted between 31 May and 3 June 2016 in Warsaw (young single persons and older married or cohabitating persons with children), Łódź (young married or cohabitating persons with children) and Lublin (middle-aged married or cohabitating persons with children). The interviews were held to improve the understanding of the narrative and context of households' risk management. They were very helpful in improving the questionnaire.

Quantitative data was collected through a survey questionnaire and from representative research (CAPI, carried out by Kantar TNS SA on a random sample of the $15+$ Polish population, stratified sample $\mathrm{N}=1063$ people, held on April 21-26, 2017).

Both the qualitative and quantitative research was carried out in connection with the implementation of the Polish National Science Centre grant Insurance forethought in the change of the social security system (No. UMO-2013/11 / B / HS4 / 02160).

Additional insights were obtained from existing research on social insurance knowledge and statistical data of Social Insurance Institution.

The relevance of determinants was established based on classic statistical methods. Cross-tabs provide the initial awareness of potential links. Appropriate tests show the statistical significance of differences for particular features. Due to multi-testing, the value of $\alpha$ is equal to 0.01 . The concluding elements of the analysis comprise regression models and a tree. The latter seems to be more appropriate from the methodological perspective.

\section{Results}

Respondents taking part in the qualitative part provided meaningful input into the research and offered a view of disability risk from the perspective of a household budget and risk management. Generally, they focus their attention on daily expenditures incurred in a monthly cycle (housing, foodstuffs, car) rather than on the expenditures of the yearly cycle (holidays). An illness (child illness was mentioned frequently) and unemployment were mentioned as major risks for the household budget. Occasionally, a severe illness was mentioned, primarily due to the high costs of its treatment. 
'We talked about what happened, which now has its consequences. Now I would like to talk about unforeseen events in the future or those you anticipate, but you have absolutely no idea what it will be like, what their consequences will be.'

'A severe disease.'

[...]

'Is it possible to protect oneself against all or some of them, against the consequences of their occurrence, to protect oneself in some way?'

'Life insurance, sickness insurance.

Some are diseases that consume very large sums of money.' (Łódź)

Although insurance is mentioned from time to time, in cases of sudden emergencies, family links operate as financial safeguards.

'You are in need, you are broke. Where are you going to go first?'

'Family.' (Łódź)

The persons who use insurance do it automatically, habitually, considering taking out insurance a standard procedure of household risk management. An example given by parents and access to employee schemes seem to be very relevant in this respect.

'What are you supposed to get from your insurance?'

'First of all, it protects us in the event of an accident or breakage. Obviously, if that happens, a person cannot go to work.'

'Was it you who came up with the idea of obtaining insurance?'

'No. It has always been obvious. Parents always did it and we did it at school. Later, when only my husband has a job and I didn't, I was covered by his insurance.'

'Accident insurance?'

'Yes.'

'Are you paying for this insurance or does your employer pay?'

'My employer, that is, the payments are deducted from my salary.' (Łódź)

Self-management of protection against risks can be overwhelming. There is certainly a need for ready-touse solutions and personal advice.
'Have you done it yet or are you planning to do anything that would help you protect yourself from the consequences of any of these points [risks]?'

'I feel lost in this because if I had to personally insure against everything and have 50,000 to cover every possible scenario, I do not know if I would have any money left at all. So I would have to take a third job to earn all this money. It's a kind of vicious circle. I know that all these things can happen, but I do not really think that they will actually happen next month and I will have to cover these costs. It's more like a balance, just in case. If one of these things happens.' (Łódź)

Disability risk was not the first to be mentioned, but the topic appeared as respondents were asked more in-depth questions.

'And if you think about the future, in terms of the budget. Are there any unpredictable or predictable events, difficult to assess, of which you are in some way afraid, which you fear? Are they the same as those listed on the board, or may any new ones appear in the future?'

'There may be new ones. Loss of health, loss of physical function. Even the loss of mental capacity after an accident, external factors. It comes down to the fact that a person will not function as well as they do now.'

[...]

'I understand that this will also mean being unfit for work. Ewa, is there anything in the future that may happen to you, that you are concerned about?'

'I'm not in a situation when I don't have medicines or I need them. For now, I manage to get by. I think there may be a situation where you can be left alone, with the same budget as before, for example, if you had a husband or wife, and then you'd have to deal with it all by yourself because there would be only one source of income instead of two.' (Lublin)

Respondents recognised the importance of disability risk but mostly did not find it necessary to think about it.

Is it worth thinking about now?

'No' (x2).

'It's necessary'.

'When I am fit, I can work. If I am unfit, I cannot work.' (Lublin) 
Personal experience is significant and significantly changes the attitude. But it is difficult to transfer one's personal experience beyond one's family.

'Is raising your children by yourself relevant to this form of protection?'

'It is for me. Ten years ago my ex-partner had a stroke and I was left with no money because he had made no effort to make sure I'm provided for, then I didn't earn enough to support my child and I needed help from my relatives.' (Warsaw)

The qualitative study suggests that disability risk is not considered a priority. The perception of that risk seems to be diverse. Unemployment rather than disability-related unfitness for work is perceived as the primary factor creating the risk of assumption of debts.

Basic statistical analysis (the Shapiro-Wilk test of normality, Chi-Square test) shows a statistically significant difference for all designated factors: gender, the experience of disability within the family, age, the level of education and the self-assessment of financial situation.
Pearson Chi-Square tests allow the exclusion of the 'household income per person' as an element not significant for differentiating the perception of disability risk. The test also suggests that gender is a relatively weak predictor.

The usefulness of linear regression is relatively low due to methodological constraints. Perception of disability risk is measured according to the Likert scale, which limits the usefulness of the linear regression model. However, the stepwise procedure helps to analyse individual elements and suggests that gender and household size give little insight into the perception of disability risk.

The tree shows a significant pattern for the first and third levels of disability risk perception on a 1-5 scale. The lowest level of risk perception can be attributed to younger respondents (aged 15-24 and 25-39). Within the 25-39 category, the level of education seems to be crucial for the perception of disability risk. Higher education correlates with the lowest level of risk perception. Other age groups tend to choose the middle (third) level of risk perception. Household size can be ignored.

Table 1

Taking Into Account the Current Situation of Your Household, How do You Assess the Risk of Disability Leading to Unfitness for Work? / Do You, or any Member of Your Household, Receive a Disability Pension Based on Unfitness for Work?

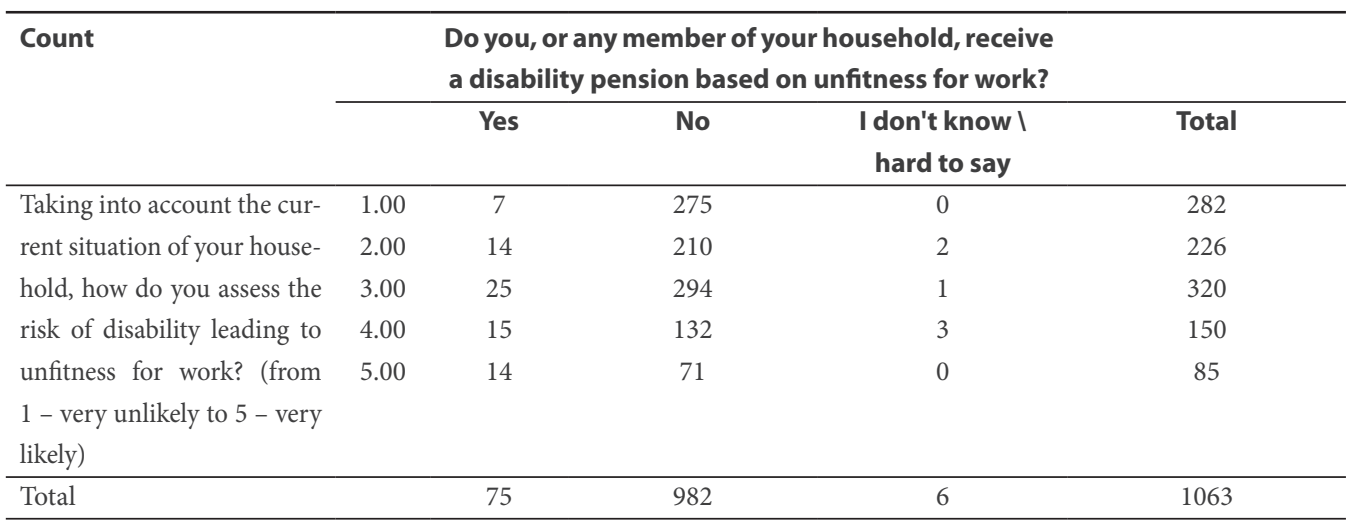


Table 2

Taking Into Account the Current Situation of Your Household, How do You Assess the Risk of Disability Leading to Unfitness for Work? / Gender

\begin{tabular}{lcccc}
\hline Count & \multicolumn{3}{c}{ Gender of the Respondent } \\
\cline { 2 - 5 } & & Male & Female & Total \\
\hline Taking into account the cur- & 1.00 & 144 & 138 & 282 \\
rent situation of your house- & 2.00 & 130 & 96 & 226 \\
hold, how do you assess the & 3.00 & 135 & 185 & 320 \\
risk of disability leading to & 4.00 & 66 & 84 & 150 \\
unfitness for work? (from & 5.00 & 38 & 47 & 85 \\
1 - very unlikely to 5 - very & & & & \\
likely) & & & &
\end{tabular}

Table 3

Taking Into Account the Current Situation of Your Household, How do You Assess the Risk of Disability Leading to Unfitness for Work? / Age Category

\begin{tabular}{|c|c|c|c|c|c|c|}
\hline \multirow[t]{2}{*}{ Count } & \multicolumn{6}{|c|}{ Age category (4 categories) } \\
\hline & & $15-24$ & 25-39 & 40-59 & 60 or more & Total \\
\hline Taking into account the cur- & 1.00 & 64 & 94 & 65 & 59 & 282 \\
\hline rent situation of your house- & 2.00 & 25 & 81 & 82 & 38 & 226 \\
\hline hold, how do you assess the & 3.00 & 31 & 88 & 120 & 81 & 320 \\
\hline risk of disability leading to & 4.00 & 9 & 31 & 47 & 63 & 150 \\
\hline unfitness for work? (from & 5.00 & 6 & 10 & 17 & 52 & 85 \\
\hline \multicolumn{7}{|l|}{1 - very unlikely to 5 - very } \\
\hline \multicolumn{7}{|l|}{ likely) } \\
\hline Total & & 135 & 304 & 331 & 293 & 1063 \\
\hline
\end{tabular}

\section{Table 4}

Taking Into Account the Current Situation of Your Household, How do You Assess the Risk of Disability Leading to Unfitness for Work? / Level of Education

\begin{tabular}{|c|c|c|c|c|c|c|}
\hline \multirow[t]{2}{*}{ Count } & \multicolumn{6}{|c|}{ Completed education level (4 categories) } \\
\hline & & Primary & Vocational & Secondary & Higher & Total \\
\hline Taking into account the cur- & 1.00 & 48 & 66 & 110 & 58 & 282 \\
\hline rent situation of your house- & 2.00 & 35 & 81 & 82 & 28 & 226 \\
\hline hold, how do you assess the & 3.00 & 55 & 129 & 105 & 31 & 320 \\
\hline risk of disability leading to & 4.00 & 35 & 69 & 40 & 6 & 150 \\
\hline unfitness for work? (from & 5.00 & 20 & 32 & 27 & 6 & 85 \\
\hline \multicolumn{7}{|l|}{1 - very unlikely to 5 - very } \\
\hline \multicolumn{7}{|l|}{ likely) } \\
\hline Total & & 193 & 377 & 364 & 129 & 1063 \\
\hline
\end{tabular}




\section{Table 5}

Taking Into Account the Current Situation of Your Household, How do You Assess the Risk of Disability Leading to Unfitness for Work? / Household Size

\begin{tabular}{|c|c|c|c|c|c|c|c|}
\hline \multirow[t]{2}{*}{ Count } & \multicolumn{7}{|c|}{ Household size (5 categories) } \\
\hline & & 1-2 person & 3-person & 4-person & 5-person & 6-person or more & Total \\
\hline Taking into account the cur- & 1.00 & 138 & 67 & 56 & 13 & 8 & 282 \\
\hline rent situation of your house- & 2.00 & 141 & 46 & 32 & 4 & 3 & 226 \\
\hline hold, how do you assess the & 3.00 & 196 & 71 & 38 & 13 & 2 & 320 \\
\hline risk of disability leading to & 4.00 & 109 & 23 & 13 & 3 & 2 & 150 \\
\hline unfitness for work? (from & 5.00 & 66 & 13 & 5 & 1 & 0 & 85 \\
\hline \multicolumn{8}{|l|}{1 - very unlikely to 5 - very } \\
\hline \multicolumn{8}{|l|}{ likely) } \\
\hline Total & & 650 & 220 & 144 & 34 & 15 & 1063 \\
\hline
\end{tabular}

Table 6

Taking Into Account the Current Situation of Your Household, How do You Assess the Risk of Disability Leading to Unfitness for Work? / Household Income Per Person

\begin{tabular}{|c|c|c|c|c|c|c|c|c|}
\hline \multirow[t]{3}{*}{ Count } & & \multicolumn{7}{|c|}{ Households by categories - income per person } \\
\hline & & $201-300$ & $301-400$ & 401-500 & $501-600$ & $601-800$ & $801-1000$ & $1001-1200$ \\
\hline & & PLN & PLN & PLN & PLN & PLN & PLN & PLN \\
\hline Taking into account the cur- & 1.00 & 1 & 0 & 1 & 0 & 17 & 13 & 26 \\
\hline rent situation of your house- & 2.00 & 0 & 0 & 1 & 0 & 10 & 13 & 19 \\
\hline hold, how do you assess the & 3.00 & 0 & 1 & 2 & 2 & 12 & 11 & 29 \\
\hline risk of disability leading to & 4.00 & 0 & 0 & 1 & 3 & 7 & 4 & 9 \\
\hline unfitness for work? (from & 5.00 & 0 & 1 & 1 & 2 & 4 & 2 & 4 \\
\hline 1 - very unlikely to 5 - very & & & & & & & & \\
\hline likely) & & & & & & & & \\
\hline
\end{tabular}

\section{Table 6 (Continued)}

\begin{tabular}{|c|c|c|c|c|c|c|c|c|c|c|}
\hline \multirow[t]{2}{*}{ Count } & \multicolumn{10}{|c|}{ Households by categories - income per person } \\
\hline & & $\begin{array}{l}1201- \\
1400 \\
\text { PLN }\end{array}$ & $\begin{array}{l}1401- \\
1600 \\
\text { PLN }\end{array}$ & $\begin{array}{l}1601- \\
1800 \\
\text { PLN }\end{array}$ & $\begin{array}{l}1801- \\
2000 \\
\text { PLN }\end{array}$ & $\begin{array}{l}2001- \\
2500 \\
\text { PLN }\end{array}$ & $\begin{array}{l}2501- \\
3000 \\
\text { PLN }\end{array}$ & $\begin{array}{l}3001- \\
5000 \\
\text { PLN }\end{array}$ & $\begin{array}{c}5000 \\
\text { PLN and } \\
\text { more }\end{array}$ & TOTAL \\
\hline Taking into account the cur- & 1.00 & 46 & 33 & 25 & 31 & 49 & 9 & 28 & 3 & 282 \\
\hline rent situation of your house- & 2.00 & 36 & 20 & 9 & 28 & 53 & 7 & 26 & 4 & 226 \\
\hline hold, how do you assess the & 3.00 & 40 & 42 & 28 & 47 & 61 & 6 & 36 & 3 & 320 \\
\hline risk of disability leading to & 4.00 & 24 & 7 & 20 & 23 & 31 & 6 & 15 & 0 & 150 \\
\hline $\begin{array}{l}\text { unfitness for work? (from } \\
1 \text { - very unlikely to } 5 \text { - very } \\
\text { likely) }\end{array}$ & 5.00 & 18 & 7 & 8 & 5 & 17 & 3 & 12 & 1 & 85 \\
\hline Total & & 164 & 109 & 90 & 134 & 211 & 31 & 117 & 11 & 1063 \\
\hline
\end{tabular}




\section{Table 7}

Taking Into Account the Current Situation of Your Household, How do You Assess the Risk of Disability Leading to Unfitness for Work? / Self-Assessment of One's Own Financial Situation

\begin{tabular}{|c|c|c|c|c|c|c|c|}
\hline \multirow[t]{2}{*}{ Count } & \multicolumn{7}{|c|}{ Self-assessment of one's own financial situation } \\
\hline & & $\begin{array}{l}\text { I am doing } \\
\text { very well }\end{array}$ & $\begin{array}{l}\text { I am doing } \\
\text { rather well }\end{array}$ & $\begin{array}{l}\text { My financial } \\
\text { situation is } \\
\text { average }\end{array}$ & $\begin{array}{l}\text { I am doing } \\
\text { rather poorly }\end{array}$ & $\begin{array}{l}\text { I am in a } \\
\text { difficult } \\
\text { financial } \\
\text { situation }\end{array}$ & Total \\
\hline Taking into account & 1.00 & 30 & 44 & 125 & 75 & 8 & 282 \\
\hline the current situation & 2.00 & 14 & 28 & 122 & 57 & 5 & 226 \\
\hline of your household, & 3.00 & 15 & 32 & 168 & 103 & 2 & 320 \\
\hline how do you assess the & 4.00 & 2 & 10 & 83 & 52 & 3 & 150 \\
\hline $\begin{array}{l}\text { risk of disability lead- } \\
\text { ing to unfitness for } \\
\text { work? (from } 1 \text { - very } \\
\text { unlikely to } 5 \text { - very } \\
\text { likely) }\end{array}$ & 5.00 & 1 & 9 & 28 & 39 & 8 & 85 \\
\hline Total & & 62 & 123 & 526 & 326 & 26 & 1063 \\
\hline
\end{tabular}

Table 8

Pearson Chi-Square Tests for Particular Determinants

\begin{tabular}{lccc}
\hline & Value & df & $\begin{array}{c}\text { Asymptotic } \\
\text { (2-sided) }\end{array}$ \\
\hline $\begin{array}{l}\text { Do you or any of the members of your household receive a dis- } \\
\text { ability pension based on unfitness for work? }\end{array}$ & $31.552^{\mathrm{a}}$ & 8 & .000 \\
Respondent's gender & $14.898^{\mathrm{b}}$ & 4 & .005 \\
Age category & $126.744^{\mathrm{c}}$ & 12 & .000 \\
Level of education & $56.424^{\mathrm{d}}$ & 12 & .000 \\
Household size & $46.616^{\mathrm{e}}$ & 16 & .000 \\
Household income per person & $64.895^{\mathrm{f}}$ & 56 & .194 \\
Self-assessment of the financial situation & $69.732^{\mathrm{g}}$ & 16 & .000 \\
\hline
\end{tabular}

\section{Note:}

a 5 cells $(33.3 \%)$ have an expected count of less than 5 . The minimum expected count is .48

${ }^{\mathrm{b}} 0$ cells $(0.0 \%)$ have an expected count of less than 5 . The minimum expected count is 41.02

${ }^{c} 0$ cells $(0.0 \%)$ have an expected count of less than 5 . The minimum expected count is 10.79

${ }^{\mathrm{d}} 0$ cells $(0.0 \%)$ have an expected count of less than 5 . The minimum expected count is 10.32

e 7 cells $(28.0 \%)$ have an expected count of less than 5 . The minimum expected count is 1.20

${ }^{\mathrm{f}} 29$ cells $(38.7 \%)$ have an expected count of less than 5 . The minimum expected count is .08

${ }^{\mathrm{g}} 3$ cells (12.0\%) have an expected count of less than 5 . The minimum expected count is 2.08 
Table 9

Linear Regression Model Summary

\begin{tabular}{|c|c|c|c|c|c|c|c|c|c|}
\hline \multirow[b]{2}{*}{ Model } & \multirow[b]{2}{*}{$\mathbf{R}$} & \multirow[b]{2}{*}{ R Square } & \multirow[b]{2}{*}{$\begin{array}{c}\text { Adjusted R } \\
\text { Square }\end{array}$} & \multicolumn{5}{|c|}{ Change Statistics } & \multirow[b]{2}{*}{$\begin{array}{c}\text { Sig. F } \\
\text { Change }\end{array}$} \\
\hline & & & & $\begin{array}{l}\text { Std. Error of } \\
\text { the Estimate }\end{array}$ & $\begin{array}{c}\text { R Square } \\
\text { Change }\end{array}$ & F Change & df1 & df2 & \\
\hline 1 & $.280^{\mathrm{a}}$ & .078 & .077 & 1.19228 & .078 & 90.014 & 1 & 1061 & .000 \\
\hline 2 & $.311^{\mathrm{b}}$ & .097 & .095 & 1.18072 & .019 & 21.872 & 1 & 1060 & .000 \\
\hline 3 & $.327^{c}$ & .107 & .104 & 1.17477 & .010 & 11.761 & 1 & 1059 & .001 \\
\hline 4 & $.334^{\mathrm{d}}$ & .111 & .108 & 1.17230 & .005 & 5.464 & 1 & 1058 & .020 \\
\hline 5 & $.339^{\mathrm{e}}$ & .115 & .110 & 1.17069 & .003 & 3.917 & 1 & 1057 & .048 \\
\hline
\end{tabular}

Note:

a Predictors: (Constant), Age category (4 categories)

${ }^{\mathrm{b}}$ Predictors: (Constant), Age category (4 categories), Completed education level (4 categories)

${ }^{c}$ Predictors: (Constant), Age category (4 categories), Completed education level (4 categories), Self-assessment of the financial situation

d Predictors: (Constant), Age category (4 categories), Completed education level (4 categories), Self-assessment of the financial situation, Household size (4 categories)

e Predictors: (Constant), Age category (4 categories), Completed education level (4 categories), Self-assessment of the financial situation, Household size (4 categories), Gender of the respondent

\section{Conclusions}

Qualitative research suggests that little attention is paid to disability risk. However, the respondents are aware of this risk. The perception of the risk seems to be diverse. The respondents perceive potential financial difficulties as associated with the costs of ill health and unemployment but rarely mention disability in this context. The experience of disability in households proves to be an essential factor.

An analysis of quantitative data shows the statistical importance of the selected determinants. However, in the case of gender, the level of significance is lower as compared to other characteristics. The regression model shows relatively low predictor power, and it should be underlined that proposed determinants are not strong and explain roughly $11 \%$ of the risk perception differentiation. Step by step procedures prove a relatively lower significance of gender as compared to other factors. The tree shows the importance of age and level of education. Women tend to perceive the highest risk of disability regardless of the size of the household.
Disability risk is attributed to the lowest level by members of two younger age groups (15-24 and 25-39), which is not surprising and remains in line with sociological theories. Interestingly, however, the perception of disability risk in the 25-39 age group depends on the level of education. Highly educated persons' perception of that risk is the lowest, whereas in people with a lower level of education the perception of disability risk remains at the average level. These findings pose the question of how rational the perception of disability risk among highly educated young people is. On the one hand, it is in line with the statistics of the Social Insurance Institution according to which young and well-educated persons represent a low percentage of disability insurance claimants. On the other hand, members of this group are heavily burdened with mortgage debt, especially since they tend to be at the early stages of their repayment period. Most mortgage loans are accompanied by a life insurance policy. However, the majority of such policies offer coverage only against the insured's death providing little protection against 


\section{Figure 2}

Tree for Determinants of Disability Risk Perception

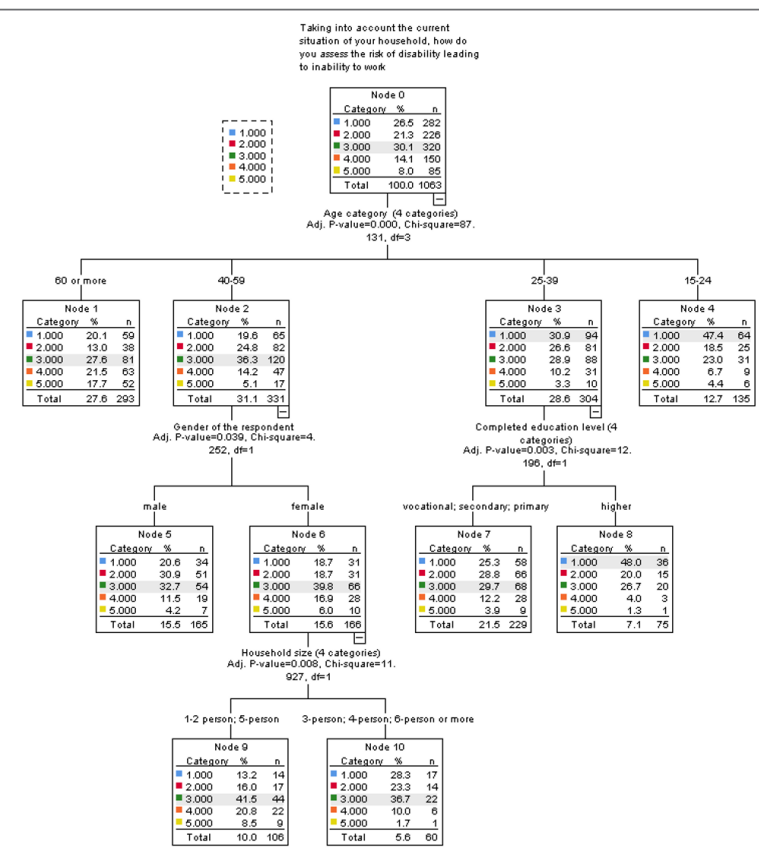

Risk

\begin{tabular}{cc}
\hline Estimate & Std. Error \\
\hline .653 & .015 \\
\hline
\end{tabular}

\section{Growing Method: CHAID}

Dependent Variable: Taking into account the current situation of your household, how do you assess the risk of disability leading to unfitness for work?

disability. Since it is in the interest of young people to be protected against disability, behavioural finance should arguably be used to provide at least a minimum level of such protection in addition to a social insurance scheme.

Income security becouse of disability is an extremely important social problem. However, the perception of this problem, knowledge of existing public solutions, the possibility of complementary/ suplementary application of private insurance, turn out to be low.

\section{References}

Babik, I., \& Gardner, E. S. (2021). Factors affecting the perception of disability: A developmental perspective. Frontiers in Psychology, 12, 2459. https:// doi.org/10.3389/fpsyg.2021.702166

Bray, N., Edwards, R. T., Squires, L., \& Morrison, V. (2019). Perceptions of the impact of disability and impairment on health, quality of life and capability. BMC research notes, 12(1), 1-6. https://doi. org/10.1186/s13104-019-4324-y

Epstein, G. (2005). Financialization and the world economy. Cheltenham and Edward Elgar. 
Finucane, M. L., Slovic, P., Mertz, C. K., Flynn, J., \& Satterfield, T. A. (2000). Gender, race, and perceived risk: The 'white male' effect. Health. Risk \& Society, 2(2), 159-172. https://doi. org/10.1080/713670162

Hyde M., \& Dixon J. (2001). Welfare ideology, the market and social security: Toward a typology of market-oriented reform. In J. Dixon, \& M. Hyde (Eds.), The marketisation of social policy (pp. 4-19). Quorum Books, Westport-London.

International Labour Organisation. (1944a). Recommendation No. 67, Recommendation concerning Income Security.

International Labour Organisation. (1944b). Recommendation No. 69, Recommendation concerning Medical Care.

International Labour Organisation. (1952). Convention No. 102. Convention concerning Minimum Standards of Social Security..

Kahan, D. M., Braman, D., Gastil, J., Slovic, P., \& Mertz, C. K. (2007). Culture and identity-protective cognition: Explaining the white-male effect in risk perception. Journal of Empirical Legal Studies, 4(3), 465-505. https://doi.org/10.1111/ j.1740-1461.2007.00097.x

Kahneman D., \& Tversky A. (1979). Prospect theory: An analysis of decision under risk. Econometrica, 47, 263-291. https://doi. org/10.1142/9789814417358_0006

Kelley-Moore, J. A., \& Ferraro, K. F. (2004). The black/ white disability gap: persistent inequality in later life? The Journals of Gerontology Series B: Psychological Sciences and Social Sciences, 59(1), 3443. https://doi.org/10.1093/geronb/59.1.S34

Manton K.G., \& Stallard E. (1997). Health and disability differences among racial and ethnic groups. In L. G. Martin, \& B. J. Solo (Eds.), Racial and ethnic differences in the health of older Americans (pp. 43-105). National Academies Press.

Nuru-Jeter, A. M., Thorpe Jr, R. J., \& Fuller-Thomson, E. (2011). Black-white differences in self-reported disability outcomes in the US: early childhood to older adulthood. Public Health Reports, 126(6), 834-843. https://doi. org/10.1177/003335491112600609

Organisation for Economic Co-Operation and Development (OECD). (2020). Adult mental health. In Health at a glance: Europe 2020: State of health in the EU Cycle. OECD Publishing. https://doi. org/10.1787/82129230-en

Paek, H.J., \& Hove, T. (2017). Risk perceptions and risk characteristics. In Oxford Research En- cyclopedia of Communication. Oxford University Press. https://doi.org/10.1093/acrefore/9780190228613.013.283

Sawyer, M. (2013). What is financialization? International Journal of Political Economy, 42(4), 5-18. https://doi.org/10.2753/IJP0891-1916420401

Slovic, P. (2010). The feeling of risk: New perspectives on risk perception. Routledge.

Szumlicz T. (2015). Ubezpieczenie w polityce społecznej - teksty i komentarze. Fundacja Instytut Zarządzania Ryzykiem Społecznym.

United Nations. (2006). Convention on the rights of people with disabilities (UNCRPD). https://www. un.org/development/desa/disabilities/convention-on-the-rights-of-persons-with-disabilities. html

World Health Organization. (2017). Rehabilitation in health systems. WHO. 